\title{
o-アセチルベンゾフェノンとアミノ酸との呈色反応
}

(1977 年 7 月 28 日受理)

南谷 晴子・前川 悦 朗*

のーフセチルベンソファノン〔1]は人間の皮店に付着すると数

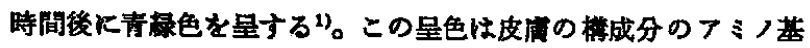
との反応によるるのと推定し，比较のためにタンパ貿中のアミ ノ酸 24 種との量色反砈を行なった。その結果、これらの色调は 大別すると五つの型にわけられる。代表的な量色とその漫収極大 の位置は衣 1 飞示すか;，皮问上での呈色飞類似しているのは Zシステインの掝合のみであった。な报，L-システンおよび第二級 フミンであるレーブロリン，L-ヒドロキシブロリンはまったく量色 しない。

そこで レ システインと[1]との反応混合物から色秦の単離を

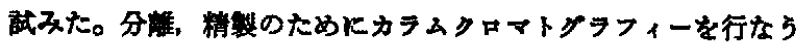

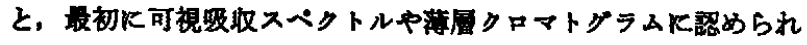
なかった色を示寸部分が現われてくる。これは -SH の反応性の ためでると推定し, 比整のために Sーメチル-らーシステインを合 成して〔1]との反応を行なった。この反忘混合物から単雄され た青色色䅈 [2a $]$ は第一䄲アミンと[1]との反応から得られる

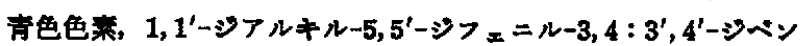

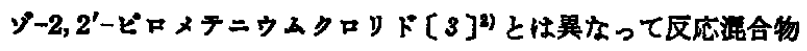
を塩㖁で処理しなくても安定に単離できる。[2a]の組成は元素 分析值と䆩量スペクトルから $\mathrm{C}_{38} \mathrm{H}_{28} \mathrm{~N}_{2} \mathrm{O}_{2} \mathrm{~S}$ であり，その楼造は NMR, UV ならびK IR スベクトルを考感して，1-(1-カルボキ

Table 1 Color reaction of o-acetylbenzophenone [1] with amino acids ${ }^{a}$ )

\begin{tabular}{cll} 
Amino acids & \multicolumn{1}{c}{ Color after $24 \mathrm{hrs}$} & \multicolumn{1}{c}{$\lambda_{\max }(\mathrm{nm})$} \\
\hline Cys & Light yellowish-green & \multicolumn{1}{c}{427,620} \\
Val & Light blue & 619 \\
Ile & Light bluish-green & 622 \\
Lys & Deep reddish-violet & 557,609 \\
Arg & Reddish violet & 567,613 \\
His & Violet-red & 418,570 \\
Trp & Violet-red & 452,557 \\
Gly & Deep reddish-violet & $530(\mathrm{sh}), 557,620$ \\
Met & Violet & $526,565,621$
\end{tabular}

a) To a solution of $5 \times 10^{-3} \mathrm{~mol}$ of $[1]$ in $5 \mathrm{ml}$ of methanol were added $10^{-4} \mathrm{~mol}$ of amino acid in a small amount of water and $1 \mathrm{ml}$ of acetic acid and the mixture was left to stand at room temperature.

b) On further standing at room temperature, the color of the reaction mixture turned into deep bluishgreen with increasing absorption intensity at 620 nm.

* 名古星工粪大学工䅈化学科, 466 名古星市昭和区御器新町

1) E. Maekawa, Y.Suzuki, S. Sugiyama, Chem. Ber., 101, 847(1968).

2）南谷倩子，前川悦朗，日化，1974，1953；1975，1535.
シー2-メチルチオエチル) $-5,5^{\prime}-シ ゙ フ ェ ニ ル-3,4: 3 ', 4^{\prime}-$ ジベンゾー 2,2'ーピロメテンと推定される。<smiles></smiles>

[2a]

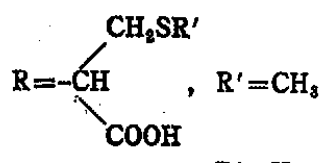

[2b]

[4] $\mathbf{R}=\mathbf{H}$

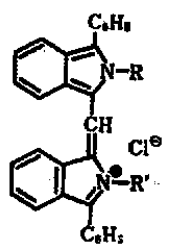

[3] $\mathrm{R}=\mathrm{R}^{\prime}=\mathrm{CH}_{8}, \mathrm{C}_{2} \mathrm{H}_{5},\left(\mathrm{CH}_{8}\right)_{2} \mathrm{CH}_{2}$ (H)-, $\mathrm{C}_{6} \mathrm{H}_{5} \mathrm{CH}_{2}, \mathrm{C}_{6} \mathrm{H}_{3}$

[5] $\mathrm{R}=\mathrm{CH}_{2} \mathrm{COOH}$

$\mathbf{R}^{\prime}=\mathrm{CH}_{2} \mathrm{CO}_{2} \odot$

(without $\mathrm{Cl} \Theta$ )

ここで[2a]Kおいてはどロメテンの一方の窒慗原子に性 [3]

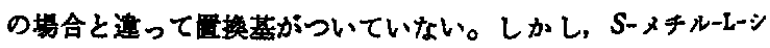
ステインが[3]のようなどロメテニウム塩を生成してから $N$-置 基が㤌ずれたのか，反応のさいK Sーメチル-Lーシステインが分

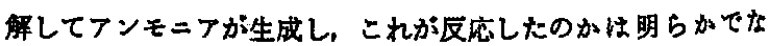

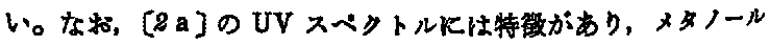
溶液ではアセトン溶湤にくらべて吸収極大の位慨がいらじるしく 長波長側へ移轩する $\left(\lambda_{\max } 546 \mathrm{~nm}\right.$ (フセトン) 一 $\rightarrow \lambda_{\max } 690 \mathrm{~nm}$ $(\mathrm{MeOH})$ )。

さきに述べたように Lーシステインとの反応で得られる青色色 美俚分離, 精制に困難な点が多いが, 得られた青色色菜の一のは 収量が非常に少ないけれどす，UVスベクトルが[2a]と同粎に 溶媒によっていちしてるしく是なること（ $\lambda_{\max } 536 \mathrm{~nm}$ (フセトン) $\left.\longrightarrow \lambda_{\max } 614 \mathrm{~nm}(\mathrm{MeOH})\right)$, ならび筫量スベクトルの特敞加ら $[2 \mathrm{~b}]$ の棈造式をるつと推定される。すなかち，質量スベクトル を比敉すると

[2 a] $m / e 470\left(\mathrm{M}^{+}-\mathrm{CO}_{2}\right)$ $m / e \quad 468\left(\mathrm{M}^{+}-\mathrm{CO}_{2} \mathrm{H}-\mathrm{H}\right) \quad\left[>\mathrm{N}-\mathrm{CH}=\mathrm{CH}_{2}\right]^{+}$ 
$m / e \quad 422\left(\mathrm{M}^{+}-\mathrm{CO}_{2} \mathrm{H}-\mathrm{SCH}_{8}\right) \quad\left[\supset \mathrm{N}-\mathrm{CH}=\mathrm{CH}_{2}\right]^{+}$

[2 b] $m / e 456\left(\mathrm{M}^{+}-\mathrm{CO}_{2}\right)$

$m / e \quad 454\left(\mathrm{M}^{+}-\mathrm{CO}_{2} \mathrm{H}-\mathrm{H}\right) \quad\left[>\mathrm{N}-\mathrm{CH}=\mathrm{CH}-\mathrm{SR}^{\prime}\right]^{+}$

$m / e$ 422( $\left.\left.\mathrm{M}^{+}-\mathrm{CO}_{2} \mathrm{H}-\mathrm{SH}\right) \quad \mathrm{DN}-\mathrm{CH}=\mathrm{CH}_{2}\right]^{+}$

となり,フラグメンテーションの特徽がよく一致する。

なお，これらの青色色来 $[2 \mathrm{a}, \mathrm{b}]$ の生成のさいKは [1]と丁

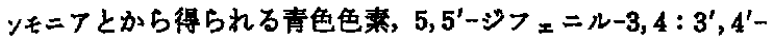

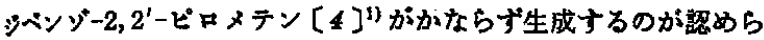

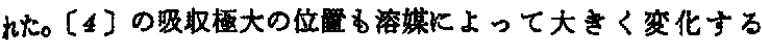

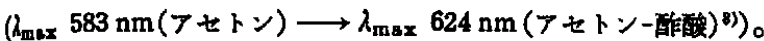

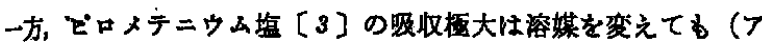

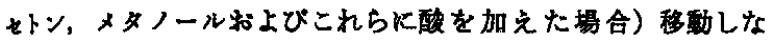
Wo

また, ゆっとも符単なてミノ酸であるク゚リシンと [1]とから 壮青色ならびに赤色色素が得られたが゙，この青色色素 [5]は [3]と類似の棈造をるち，[3]のように塩酸塩ではなく分子内 曹をつくっていることが確かめられた。この[5]の UV スペク トル $\left(\lambda_{\max } 621,297,273 \mathrm{~nm}(\mathrm{MeOH})\right)$ と [2a $]$ のそれ (実悇 の部）とを比校して[2a]はフセトン中ては一方の空菜原子のと ころに非共有電子対が存在するが，メタノール中で忙その酸性の ために $>\mathrm{N} \oplus \mathrm{H}$ となり[5]と同じ共役禾をむつるのと考えられ bo

\section{璂 験}

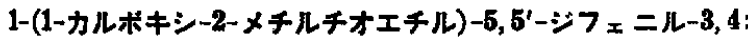
3',4'-シベンソピロメテン [2a]

(1] $560 \mathrm{mg}$ の $90 \%$ 含水土タノール溶液 $(60 \mathrm{ml})$ KS-メチ

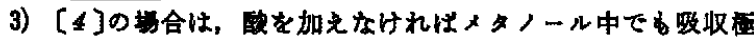

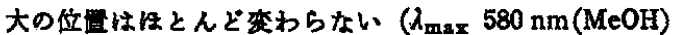

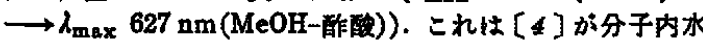

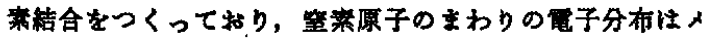
タノールの破性によっては汪とんど影算をうけないためと 考えられる.

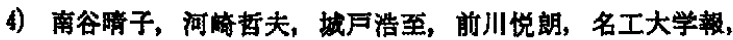
$27,151(1975)$.

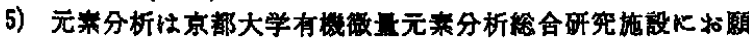

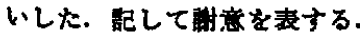

6) V.duVigneaud, H.S. Loring, H. A. Craft, J.Biol. Chem., 105，481(1934) としたがって合成した.

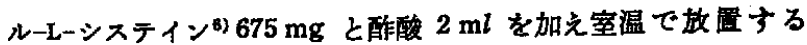
(S-メチル-Lーシステインは完全に溶けないがそのまま放膡し た） 30日後，末反応の S-メチル-Lーシスティンを沪別してから カラムクロマトグラフィーを行ない (Mallinckrodt シリカゲル, $100 \times$ ッュ)，最初ベンゼンで溶出する部分から（4]が得られ た。ベンゼンークロロホルム $(1: 1)$ で溶出する副生成物を除いて から $2 \%$ のメタノールを含むベンゼンークロロホルムで容出する

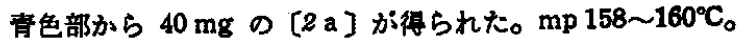

分析陋 C 76.34\%, H $5.52 \%, N 5.06 \%$, $07.18 \%, S 6.50 \%$

$\mathrm{C}_{33} \mathrm{H}_{28} \mathrm{~N}_{2} \mathrm{O}_{2} \mathrm{~S} \cdot 1 / 3 \mathrm{H}_{2} \mathrm{O}$ としての

訫算値 C $76.13 \%, H 5.17 \%$, N $5.38 \%$, o $7.16 \%$, s $6.16 \%$

MS : 前記

$\lambda_{\text {max }}(\mathrm{MeOH})(\mathrm{nm}) ; 630(\varepsilon=67300), 577(\mathrm{sh})(\varepsilon=29800), 299$ $(\varepsilon=18200), 270$

$\lambda_{\max }(\mathrm{MeOH}-\mathrm{HOAc} 9: 1)(\mathrm{nm}): 630(\varepsilon=75600), 299(\varepsilon=14900)$, $275(\varepsilon=16800)$

$\lambda_{\max }($ フセトン) $(\mathrm{nm}): 546(\varepsilon=50500), 375$

$\operatorname{NMR}(\delta)\left(\mathrm{CDCl}_{\mathrm{g}}\right): 12.5$ (br., $1 \mathrm{H}$ カルボン酸), 9.1〜6.7(m, 19H，芳香環およびこれK共役したメチy)，5.73〜 5.27(m, 1H， $\mathrm{N}-\mathrm{CH}), \quad 3.78 \sim 3.27\left(\mathrm{~m}, 2 \mathrm{H},-\mathrm{CH}-\mathrm{CH}_{2}-\mathrm{SCH}_{8}\right), 1.53(\mathrm{~s}, 3 \mathrm{H} \mathrm{s}-$ $\left.\mathbf{C H}_{\mathbf{8}}\right)$

$\operatorname{IR}\left(\mathrm{cm}^{-1}\right): 1690\left(\nu_{\mathrm{O}-\mathrm{N}}\right), 1610$ と $1420\left(\nu_{\mathrm{cO}}\right)$

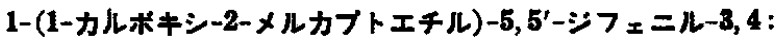
$3^{\prime}, 4^{\prime}$-ジベンソビロメテン [2 b]

[1] $560 \mathrm{mg}$ と L-システイン $605 \mathrm{mg}$ とから [2a]の湯合 と同じよに处理して [4]と [2 b] 2 3 mgが得られた。 $\mathrm{mp}$ 160 166C に不溶の部分は水に溶けて黄像色を是するが，放盖したさい析出 する固体はおるによーシスチンであった。

MS : 前梀

$\lambda_{\text {max }}(\mathrm{MeOH})(\mathrm{nm}): 614,446(\mathrm{sh}), 381,360,295(\mathrm{sh})$

$\lambda_{\max }(\mathrm{MeOH}-\mathrm{HOAc}): 616,446(\mathrm{sh}), 382,360,290$

$\lambda_{\max }(7$ セン)(nm) $: 536,405(\mathrm{sh}), 370$

IR $\left(\mathrm{cm}^{-1}\right): 1685\left(\nu_{0-N}\right), 1610$ と $1420\left(\nu_{0 O}\right)$

Color Reactions of o-Acetylbenzophenone with Amino Acids

Seiko Nan'ya and Eturô Maekawa

Nagoya Institute of Technology ; Showa-ku, Nagoya-shi 466 Japan

Inspection of the color reactions between o-acetylbenzophenone [1] and twenty four amino acids present in proteins revealed that only the coloration with L-cysteine was analogous to that with human skin.

On the color reactions of [1] with $S$-methyl-L-cysteine and of [1] with L-cysteine, deep blue pigments, $\mathrm{C}_{82} \mathrm{H}_{28} \mathrm{~N}_{2} \mathrm{O}_{2} \mathrm{SR}([2 \mathrm{a}](\mathrm{R}=\mathrm{Me})$ and $[2 \mathrm{~b}](\mathrm{R}=\mathrm{H})$, respectively) were isolated. The structures of $[2 \mathrm{a}]$ and $[2 \mathrm{~b}]$ were determined as 1-(1-carboxy-2-methylthioethyl)- and 1-(1-carboxy-2-mercaptoethyl)-5, 5'-diphenyl-3,4:3', $4^{\prime}$-dibenzo-2, 2'-pyrromethenes, respectively, on the basis of their IR, UV, NMR and MS-spectra. 